\title{
Digital Technologies for Heritage Teaching: Trend Analysis in New Realities
}

\author{
https://doi.org/10.3991/ijet.v16i21.25149 \\ Jacob Vargas Arteaga ${ }^{1}(\sqrt{ })$, Marbel Lucía Gravini-Donado ${ }^{1}$, \\ Lorenzo Domenico Zanello Riva ${ }^{2}$ \\ ${ }^{1}$ Universidad Simón Bolívar, Barranquilla, Colombia \\ ${ }^{2}$ Altamira International School, Barranquilla, Colombia \\ jacob.vargas@unisimon.edu.co
}

\begin{abstract}
The irruption of digital technologies in social contexts and their integration in education has led to new learning environments where the communication, interaction and access to knowledge are an essential part of the educational process. This paper shows a literature review and mapping of the most important technological tools used in the contexts where heritage teaching has been conducted in the last decade. For this aim developed a bibliometric analysis of scientific publications in high impact journals through selective searches in the specialized databases Scopus and Science Direct. The findings show trends in the educational practice approach regarding heritage, integrating emerging technologies such as augmented reality, 3D modelling, artificial intelligence, QR coding and virtual reality that offer situated and immersive learning experiences on mobile apps and web-based platforms. From the studies analyzed in different contexts, it is concluded that the integration of digital technologies in the teaching and heritage appropriation is a field that in recent years shows a clear increase, so that it is necessary to consider the potential of these tools in it's diffusion, teaching and preservation to strengthen existing work lines and open up possibilities to future studies.
\end{abstract}

Keywords - heritage, heritage education, digital technologies, ICT, heritage teaching

\section{Introduction}

ICT have burst vertiginously into people's lives, becoming a support for multiple processes in different contexts of application and transforming the forms of communication and social interaction. Likewise, in the educational context they have positioned themselves as mediation and learning tools in various disciplines, changing the way in which knowledge is accessed and transferred, expanding the educational offer from the presentation of information in multiple formats, allowing access to more content and digital resources for learning [1], [2], creating revolutions that give rise to innovation scenarios [3]. 
Due to this, this type of resources are an important factor in the generation of new spaces for knowledge and self-training of people, so it is relevant to analyze the relationships and interactions that may arise when using digital technologies in education.

Regarding heritage, there has recently been a growing interest in considering a new vision of this concept to refer not only to material goods, but to all the manifestations that are part of culture and that sustain the identity of social groups. Nevertheless, a greater effort is still needed to completely overcome the historicist vision of heritage towards a new conception that places heritage close to people, since it is they who are in charge of safeguarding, valuing and transmitting it [4]-[6]. Particularly, this position focuses on the links that develop between heritage assets and people, as factors to be considered in the teaching and didactics of heritage, as they are products derived from processes of valorization and construction of identity.

Thus, e-tools contribute significantly to the teaching of heritage assets, by integrating various technologies and resources that not only allow the generation and transmission of heritage contents, but also the management of educational processes based on them. Hereby, ICTs provide new scenarios for the consolidation of relationships and the creation of meanings [7], giving rise to situated and experiential learning through the communication of contents, bringing people closer to cultural assets, establishing connections and becoming a support for heritage education processes. Recent studies have therefore focused on showing the contribution of digital technologies when teaching many disciplines, especially heritage. By implementing, immersive learning experiences. [8], [9].

Despite the fact that in recent years the literature related to educational strategies around heritage assets has been growing, few reviews have been developed in the line of work related to the inclusion of ICTs in heritage education. The main researches that stand out are oriented to the evaluation of educational programs on tangible and intangible heritage [10], to heritage processes from an educational perspective [11] and to the analysis of doctoral theses, articles and conference proceedings on heritage education [12], [13]; all of them working secondarily on the issue of the integration of technologies. Among the few review studies on the approach to heritage with the use of digital technologies, there are some whose interest is focused on examples of good practices in the adoption of ICT in heritage education based on the fulfillment of standardized criteria [14], teacher training for technological mediation in museums [15], interactivity in museums [16] and the formation of links and identities [17].

Considering that the previous experiences focus on specific contexts and programs, this study aims to analyze experiences related to heritage education beyond museums and heritage preservation institutions, also considering formal environments such as universities or schools and experiences at the informal level where communication, dissemination, preservation and enhancement of heritage take place, taking into account the largest possible number of technologies that have been adopted in this line of research. A systematic literature review is proposed to help elucidate the main contributions and emerging categories related to the use of digital technologies in the teaching and learning of heritage. To this end, we start from two research objectives: 
1. Analyzing the publications in high impact journals that have been developed in relation to the use of digital technologies for heritage teaching in the last ten years (2010-2020).

2. It identifies the technologies used and the emerging trends in the teaching, learning and appropriation of heritage in different contexts.

The study seeks to provide valuable elements that can be integrated into a theoretical corpus in the field of heritage teaching and didactics, as a contribution to the study of the use and appropriation of digital technologies in education.

\section{Methodology}

During the development of this study, the literature review is conceived as a systematic and objective process to achieve the purposes of the research by approaching the body of research published in high-impact scientific journals. Viewed from this perspective, the recommendations of the PRISMA (Preferred Reporting Items for Systematic Reviews and Meta-Analyses) statement are followed to guarantee the criteria of quality, transparency and rigor of the study [18].

Hence, inclusion and exclusion criteria were defined to delineate a group of potentially relevant studies to be considered in the analysis. Research articles published between 2010 and 2020 whose thematic areas were Social Sciences, Arts and Humanities, in open access, in Spanish and English and that were related to the use or validation of technologies in heritage education in different fields were only taken into account. We excluded documents that were not available for downloading in full text, reports, essays, conference proceedings or studies developed in other disciplines that did not have an educational intention or those that, although related to heritage, did not include the use of digital technologies.

Selection of the articles was based on a search of the Scopus and Science Direct databases according to their relevance, volume of publications and worldwide recognition as one of the main sources of scientific publication and indexing of high-impact journals. Harzing and Alakangas [19] point out that in systematic literature reviews it is necessary to use databases that provide stability and sufficient coverage.

On the search protocol for research articles was located in the period 2010-2020 using the following keywords in English: heritage, heritage education, heritage educational, heritage educational, teaching, program, programs, combined by means of logical operators with ICT, Digital technologies, Technological. The following search string was run: ((heritage education) OR (heritage teaching) OR (heritage educational programs) $O R$ (heritage education program) OR (heritage educational programs) $O R$ (heritage education ICT) OR (heritage ICT) OR (heritage Digital technologies) OR (Technological and heritage)).

Query results were further filtered to open access papers only, period specific, restricting titles, abstracts, and keywords to the specific search terms. The search yielded 805 articles, of which 722 came from Scopus and 83 from Science Direct; all were extracted and imported into the Mendeley reference manager and organized in a spreadsheet for preliminary analysis. 


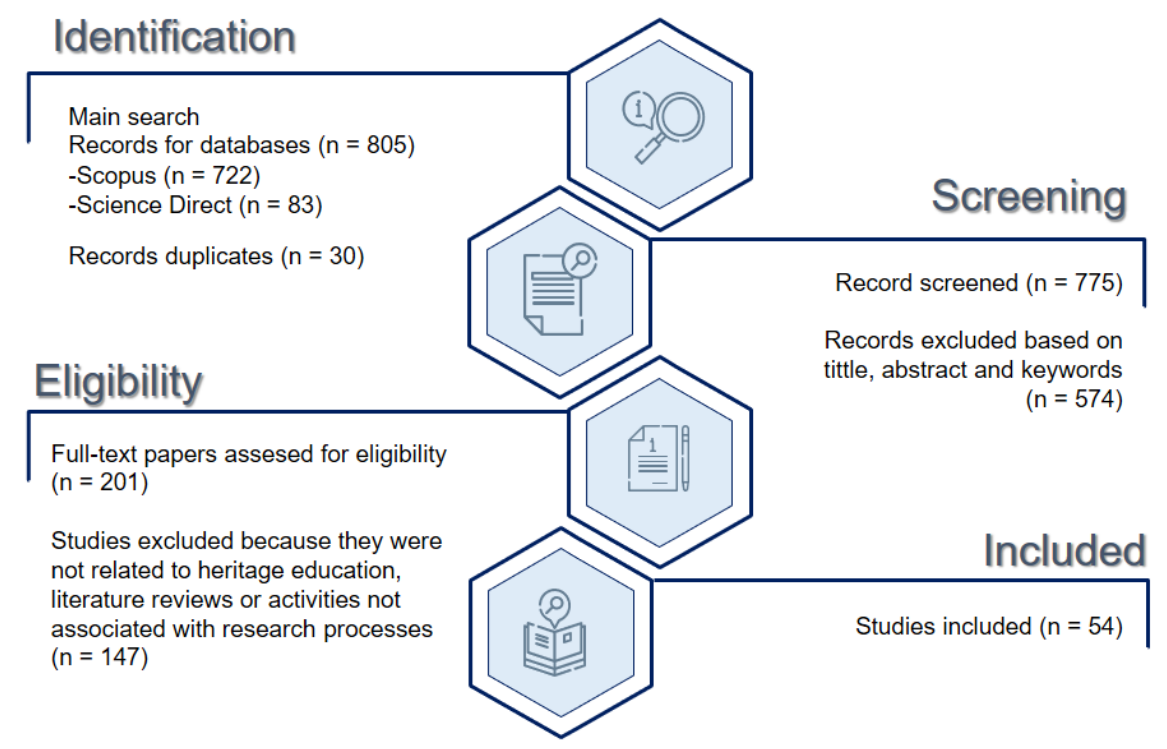

Fig. 1. Process of identification and selection of studies from PRISMA.

From the first phase of review by title and abstract, 574 documents and 30 duplicates were excluded. A total of 201 documents were downloaded for full-text review, selecting 54 articles for detailed analysis according to previously defined inclusion criteria (Fig. 1). Results articles were imported into MAXQDA 2020 software for an initial scan seeking to analyze keyword frequencies, cooccurrences and code generation based on inductive categorization and to gain an understanding of the lines of research that have been developed around the purposes of this study. Microsoft Excel and Vosviewer were used for quantitative analysis, systematization and data visualization.

\section{$3 \quad$ Results}

Primary objective of the study has been to determine the volume of publications, trends, categories and themes emerging from the review in relation to the use of digital technologies in heritage teaching and learning. Therefore, the results are presented in terms of the research objectives proposed in the study.

\subsection{The bibliometric perspective of publications related to the use of digital technologies in heritage teaching}

Related to the first objective of the study, the bibliometric analysis provides relevant information on scientific publications in terms of volume, evolution, dissemination and visibility, which allows an objective evaluation of the impact of scientific publications and their sources [20]. A rigorous selection process was therefore carried out to determine the number of studies relevant to the analysis. The results show an evident growth 
of academic production in this line of research in the last ten years, with a clearly increasing trend in the number of publications.

Figure 2 shows that between 2012 and 2018 the number of publications remained stable, but subsequently there has been an accelerated increase in the last three years. Aforementioned demonstrates the growing interest around this topic in high impact journals and a higher degree of dissemination could be expected in the coming years, although this number is extremely low and insignificant compared to the large volume of publications produced today in the scientific community.

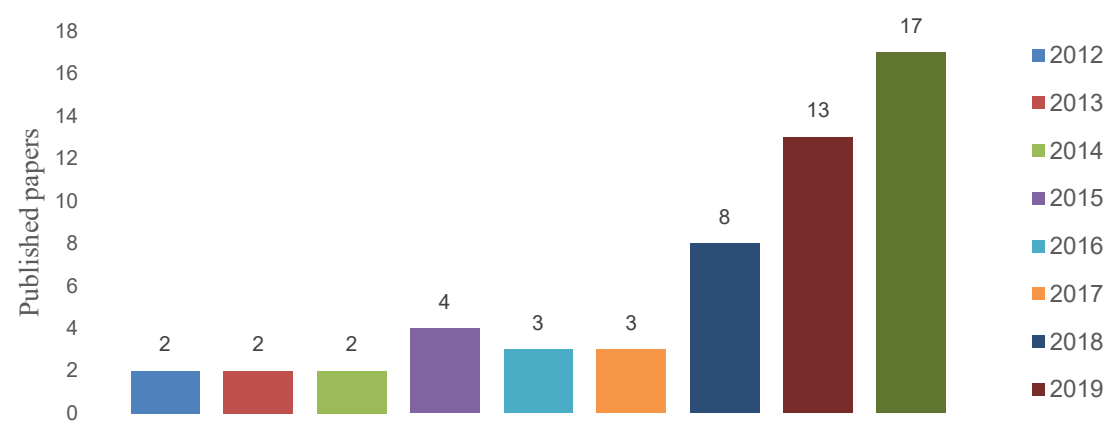

Fig. 2. Number of publications per year

As regards country of origin, the articles are distributed among 19 countries; $81 \%$ are concentrated in nine countries, with Spain being the country with the highest participation in the publications with $37 \%$, followed by Greece with $9 \%$, Italy with $7 \%$, the United Kingdom with $7 \%$, Portugal with $6 \%$, Colombia with $4 \%$, the Netherlands with $4 \%$, Romania with $4 \%$ and the United States with $4 \%$. Other countries have equal participation with $2 \%$ of the total number of publications. This information may be useful for researchers interested in establishing networks and collaborative activities related to the research topic, either through co-authorship in publications, participation in academic events or internships.

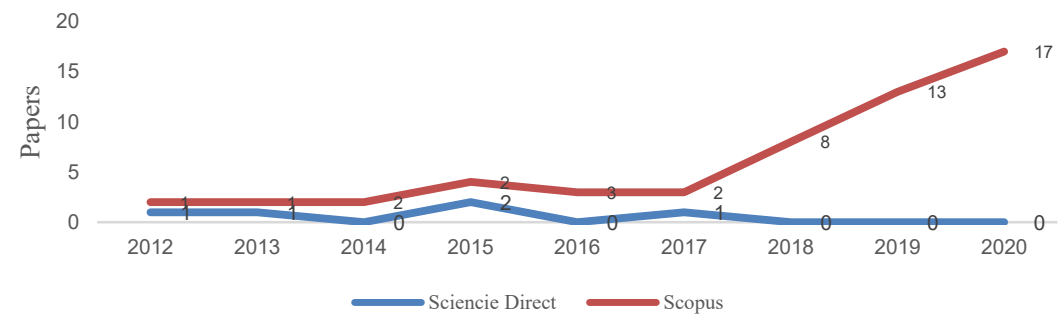

Fig. 3. Comparative progression of scientific production in Scopus and Science Direct.

Moreover, the publication of the articles submitted for analysis is concentrated in 31 journals, whose information was consulted in SCImago Journal \& Country Rank (SJR) 
to determine the quality and impact factor, although it was found that some of them are not indexed.

In Table 1, the ten most relevant journals, their quartile in the SJR 2020 ranking, the impact factor and the number of articles published are shown. It is pertinent to note that of the total number of articles selected, $48 \%$ were published in these journals. Such information could be useful for researchers, research centers, educational institutions whose lines of research focus on the use of technologies in the appropriation of heritage, so these metrics can point out opportunities to consolidate and make their publications visible.

Table 1. SJR ranking of the most representative journals

\begin{tabular}{|c|c|c|c|}
\hline Quartile & Journal & Factor of Impact (FI) & Articles Papers \\
\hline \multirow{4}{*}{} & International Journal of Heritage Studies & 0,696 & 1 \\
\cline { 2 - 4 } & Sustainability & 0,612 & 10 \\
\cline { 2 - 4 } & Virtual Archaeology Review & 0,450 & 6 \\
\cline { 2 - 4 } & Space and Culture & 0,426 & 1 \\
\cline { 2 - 4 } & Advances in Archaeological Practice & 0,425 & 2 \\
\cline { 2 - 4 } & Journal on Computing and Cultural Heritage & 0,371 & 1 \\
\cline { 2 - 4 } & Museum Management and Curatorship & 0,307 & 1 \\
\hline \multirow{4}{*}{ Q2 } & Revista Complutense de Educación & 0,466 & 2 \\
\cline { 2 - 4 } & Education Sciences & 0,453 & 1 \\
\cline { 2 - 4 } & Arbor & 0,154 & \\
\hline
\end{tabular}

Citations received by the articles published in the 31 journals were also reviewed, and the information was organized in Table 2, displaying the ten most relevant journals according to the number of citations received in the articles published in the selected period.

Table 2. Journals with the most citations received in Scopus

\begin{tabular}{|l|c|}
\hline Journal & Cites Received \\
\hline Sustainability (Switzerland) & 71 \\
\hline Procedia Computer Science & 34 \\
\hline Virtual Archaeology Review & 21 \\
\hline Design Journal & 14 \\
\hline Arbor & 8 \\
\hline Advances in Archaeological Practice & 7 \\
\hline Revista Electrónica Interuniversitaria de Formación del Profesorado & 7 \\
\hline International Journal of Emerging Technologies in Learning & 6 \\
\hline Munibe Antropologia-Arkeologia & 6 \\
\hline Museum Management and Curatorship & 6 \\
\hline
\end{tabular}

Notably, the journal Sustainability occupies first place with the highest number of citations (71), of which 67\% are concentrated in three articles. Noteworthy here are the studies by Martínez-Graña et al. [21] with 26 citations, the work of Dollani et al [22] 
with 14, and the study by Gomez-Oliva et al. [23] with 8 citations received. Indeed, the impact of this journal is evident since all the articles published and that were the subject of this analysis have at least one citation, even those of more recent publication. Thereby, the greatest contribution of the information presented in Table 2 consists in providing the research community with valuable elements that they can take into account when making their publications, since the visibility of scientific production is of great relevance as a means to achieve greater social appropriation of knowledge.

Regarding the educational setting in which the studies were carried out, $60 \%$ of the research experiences were developed in non-formal settings, $15 \%$ in primary schools, $11 \%$ in secondary schools and $14 \%$ in technical or higher education institutions. Regarding the methodological approach of the studies, $52 \%$ are quantitative designs, $35 \%$ qualitative and $13 \%$ with mixed methods. Further, these data can be considered of great importance when addressing research proposals that include technologies for heritage education in different areas, considering the methodological richness of the approaches and thus being able to respond to research interests.

\subsection{Emerging trends analysis related to the use of digital technologies in heritage education}

Answering the second objective of this study, a co-occurrence analysis of relevant terms defined by the same authors is initially presented. Such a procedure is an efficient procedure to discover emerging trends from the relationships between keywords within the same context [24].

The data were loaded into the VosViewer software [25] for visualization after debugging the keywords of the articles. In order to obtain a meaningful list that would result in a map of relationships easy to analyze and understand, only terms whose frequency was equal to or higher than 3 were considered.

Figure 4 illustrates the bibliometric map generated by the Vosviewer software from all the keywords contained in the 54 selected articles. It also shows the network of relationships between the terms, with some being stronger than others, which can be understood from the proximity between the labels. Based on this visualization, five clusters were identified, generated from the most frequent relationships between the keywords, which are described in Table 3.

Table 3 identifies two major clusters on which the discussion will focus in the following section, as the terms and co-occurrences describing clusters three, four, and five are closely related to the first two clusters. The most frequently occurring keywords in the articles offer new fronts of work and emerging approaches to research or theoretical dissertation related to the use of digital technologies in heritage education. Supplementing the descriptive perspective of this review, a full-text analysis of the studies was conducted to determine more precisely the research foci that emerge as a task for researchers interested in this topic. 


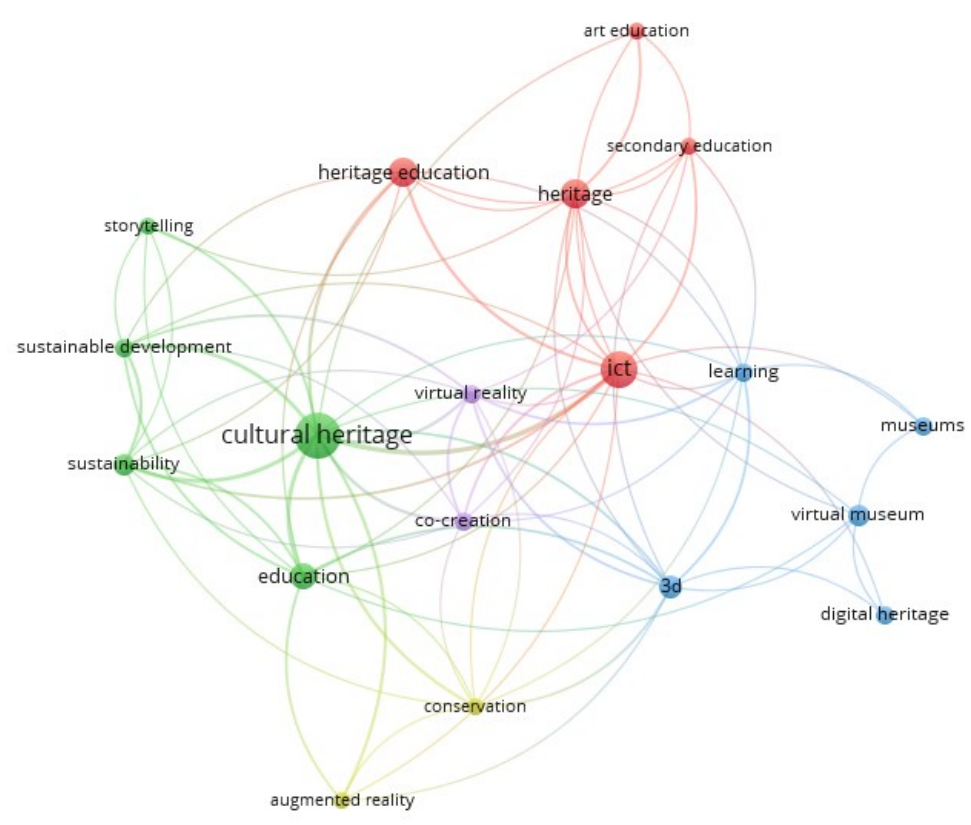

Fig. 4. Relationship map generated from the keywords.

Table 3. Clusters identified in the co-occurrence analysis

\begin{tabular}{|l|l|l|}
\hline Cluster & \multicolumn{1}{|c|}{ Description } & \multicolumn{1}{c|}{ Most related terms } \\
\hline ICT & $\begin{array}{l}15 \text { terms related to Information } \\
\text { and Communication Technolo- } \\
\text { gies (ICT) are grouped together. }\end{array}$ & $\begin{array}{l}\text { cultural heritage, education, heritage, heritage education, } \\
\text { heritage education, sustainability, sustainable develop- } \\
\text { ment, augmented reality, co-creation, conservation, digital } \\
\text { heritage, learning, museums, art education, secondary edu- } \\
\text { cation, virtual reality }\end{array}$ \\
\hline $\begin{array}{l}\text { Cultural herit- } \\
\text { age }\end{array}$ & $\begin{array}{l}\text { Clustering of 14 keywords asso- } \\
\text { ciated with cultural heritage }\end{array}$ & $\begin{array}{l}\text { storytelling, heritage education, art education, art educa- } \\
\text { tion, augmented reality, co-creation, conservation, educa- } \\
\text { tion, ICT, 3D, learning, virtual museums, sustainability, } \\
\text { sustainable development, virtual reality }\end{array}$ \\
\hline 3D & $\begin{array}{l}11 \text { words related to 3D modeling } \\
\text { techniques and applications are } \\
\text { integrated. }\end{array}$ & $\begin{array}{l}\text { cultural heritage, heritage, augmented reality, co-creation, } \\
\text { conservation, digital heritage, education, learning, second- } \\
\text { ary education, virtual museum, virtual reality }\end{array}$ \\
\hline Conservation & $\begin{array}{l}\text { Groups 9 terms related to herit- } \\
\text { age conservation strategies. }\end{array}$ & $\begin{array}{l}\text { education, cultural heritage, augmented reality, 3D, co-cre- } \\
\text { ation, ICT, learning, sustainability, virtual reality, virtual } \\
\text { reality }\end{array}$ \\
\hline Virtual reality & $\begin{array}{l}\text { It includes 9 keywords associ- } \\
\text { ated with virtual reality-based } \\
\text { applications. }\end{array}$ & $\begin{array}{l}\text { cultural heritage, ICT, conservation, co-creation, 3D, sus- } \\
\text { tainability, sustainable development, learning, secondary } \\
\text { education }\end{array}$ \\
\hline
\end{tabular}

Findings derived from the analysis of the emerging categories are presented as a basis for considering digital technologies as tools that can be introduced in a relevant and intentional way in didactic and methodological strategies for heritage teaching, since they have become tools for mediation and learning in various disciplines. 
Studies reviewed point to heritage learning experiences in museums through virtual exhibitions or the design of interactive scenarios for informal users [26]-[31] or as environments for experiential learning as an extracurricular activity [32], [33]. Outstanding studies show how museums have adapted to the new realities derived from the pandemic, venturing into the design of digital resources for the dissemination and communication of heritage and maintaining a close relationship with students, teachers, researchers and users in general. Samaroudi et al. [34] analyzed the cases of 83 institutions dedicated to heritage preservation in Europe and America. Furthermore, Rivero et al. [35] analyzed 254 museums and heritage preservation centers in Spain to learn about the strategies for education, dissemination and interaction with heritage that were adopted as a result of the closures caused by Covid-19. Among this type of experiences, the use of digital platforms, artificial intelligence [36], [37] and social networks as strategies used to maintain their training and communication programs with citizens stands out.

Meanwhile, the development of modeling techniques with 3D technology has had great relevance in recent years as a tool for the conservation of heritage assets. Applied as a complement to virtual or augmented reality [38], [39] these technologies make it possible to reach all types of audiences and contribute to the preservation of geological [21], archaeological [40]-[42] and intangible [43] heritage, involving teachers in training and also young people in the design of collaborative platforms and materials for the support, safeguarding and revaluation of the significance of heritage [44]-[46].

E-learning and m-learning experiences supported by mobile applications and the use of active methodologies have shown a positive contribution to the teaching and appropriation of heritage in various scenarios [47], [48]. The majority of the studies seek to achieve a greater dissemination of heritage values and provide greater elements of interaction to the designed applications including novel techniques such as gamification [49], interactive maps [22] or reading QR codes [50] as dynamizers of the teaching and learning processes of heritage. Along this line of work there are a good number of studies focused on the comprehensive evaluation of mobile applications, initiatives and heritage education programs that use technological platforms as a tool for management, preservation, communication and innovation in heritage didactics and teaching [51][53]. Nevertheless, although there are significant advances in the use of these technologies, it is necessary to continue working on offering tools that have a real didactic adaptation in which users can enhance skills and make use of self-learning beyond receiving content in various formats [14], [54], [55].

New technological possibilities have also been found to dynamize the communication strategies of tangible and intangible heritage by adding immersive resources such as augmented reality and video games [56]-[59], giving rise to ubiquitous learning experiences and positioning digital technologies as tools to strengthen the links between heritage and people [60] and as a strategy for its dissemination and preservation based on the participation of citizens [61], [62]. Accordingly, another line of work that stands out is the use of digital narratives in combination with other emerging technologies to intensify and enrich learning experiences about cultural manifestations or heritage assets [63]-[65]. Evidence is provided here of the value of these tools for the development of pedagogical experiences with high levels of differential interaction and as support 
for intelligent solutions for the promotion of sustainable cultural destinations [23], [66], [67].

However, there were experiences that used digital resources such as multimedia and web platforms to support memory preservation strategies, the construction of identity links or as a tool for the recognition of the historical and cultural legacy of localities [7], [42], [68], [69]. More experiences have focused on the sustainable promotion of heritage destinations and on the perception that the population has of its heritage [70], [71].

\section{Discussion}

It has been developed the proposed study based on the analysis of publications in high impact journals, in relation to the inclusion of information and communication technologies in heritage teaching processes in the last decade. Considering the results presented by the progression of scientific publications in the research line of interest, a high rate of diachronic productivity is evidenced, which is supported by the accelerated increase in the last three years. In this regard, this could be explained by the law of exponential growth explained by Price [72], who states that scientific information tends to double every 10 to 15 years, as can be seen in the graphs presented in the previous section.

Most publications are concentrated in Europe, where Spain continues to be one of the most prolific countries due to the institutional efforts that have been developed in that country to consolidate effective models of heritage educational management as demonstrated in previous studies [5], [10], [13], [15]. Further searches in other databases are worth considering, in order to obtain data on publications in Latin America in order to analyze more precisely the productivity in this context and thus provide elements of value in the dissemination and consolidation of connections between researchers from different continents to ensure greater impact and visibility.

Studies aimed at integrating innovative teaching models that consider digital technologies as tools for the dissemination, communication, safeguarding, preservation and management of tangible and intangible cultural heritage in the educational sphere have been the focus of interest in the evolution of publications on the research topic. For this purpose, more than 30 specialized journals have publications in this line of work, ten of which are those with the highest impact, which is reflected in the number of citations presented by the studies. As a consequence, it is shown that there is room for this emerging line of research, which is supported by the diachronic evolution mentioned above. Moreover, the role of digital technologies as a support in the processes of valorization, shaping of identities and creation of meanings around heritage is ratified, since the growing use of technological tools in museums confirms the possibility of building links between heritage and people from the creation of scenarios for the understanding of their social value [17], [60].

In addition, the adoption of digital technologies and the implementation of environments equipped with interactive content make museums more important at the educational level, ratifying them as meeting places for training, participation, experiential 
learning and the approach to new forms of knowledge production. Contrary to what has been found in other studies [15], the results described here show an important number of studies in which museum activity is one of the main ways of bringing heritage closer to people, opening up possibilities for consolidating synergies between educational institutions and museums. Certainly, with the use of emerging technologies and virtuality, these spaces have ratified their dialogic potential, making use of new forms of communication and interaction, whose impulse has been present mainly in the last year due to the Covid-19 pandemic.

In terms of the trends that emerge from the review, it should be noted that the keywords with the highest frequency in the selected studies coincide to a large extent with the categories derived from the in-depth analysis of the texts. Two groups of the most representative terms in the map of relationships and according to the emerging categories, the lines of work emerge as a task to be addressed in future research, since their contribution to this topic is significant. Hence, the contribution of emerging technologies such as augmented reality, 3D modeling, artificial intelligence, QR coding and virtual reality, can be positive when combined with active methodologies such as gamification in different environments, offering situated and immersive learning experiences on mobile or desktop platforms. Introduction of some of these technologies in the context of heritage education had already been described in previous reviews [14], [16], however here we ratify the possibility of integrating digital technologies in heritage education as underpinning the emergence of a field of research that deserves to be explored.

\section{Conclusions}

Evidently, the irruption of ICTs in different areas of our lives, as well as their incorporation in education, has led to the generation of new learning scenarios where communication, interaction and access to knowledge are consolidated as fundamental elements of educational processes. These findings confirm that the integration of digital technologies in the teaching and appropriation of heritage is a field that in recent years has shown considerable growth, demonstrating the multiple possibilities and contributions of these resources in the processes of dissemination, resignification and educational management of heritage.

Consequently, it is reaffirmed that digital technologies are increasingly consolidated as valuable tools to promote the linkage with heritage that leads to the creation of new meanings [7]. Moreover, this means that their integration in formal and informal contexts for heritage education can become the best ally in the new realities where training and access to knowledge is only possible to a large extent through the scenarios and possibilities provided by virtuality, overcoming the limitations of face-to-face models that deepened as a result of the pandemic.

As a result, this review is an approximation to a much broader thematic corpus, since only two high-impact databases have been considered. Research is needed to continue 
exploring other specialized repositories where the lines of work outlined here are explored in depth and to continue the search for new ways to validate the contribution of digital technologies in the approach to heritage from an educational perspective.

\section{Acknowledgement}

This study was conducted with financial assistance from the Ministry of Science, Technology and Innovation of the Republic of Colombia - MinCiencias.

\section{$7 \quad$ References}

[1] J. Viana and H. Peralta, "Online Learning: From the Curriculum for All to the Curriculum for Each Individual," J. New Approaches Educ. Res., vol. 10, no. 1, pp. 122-136, 2021, https://dx.doi.org/10.7821/naer.2021.1.579

[2] M. Area-Moreira and T. Pessoa, "From solid to liquid: New literacies to the cultural changes of Web 2.0," Comunicar, vol. 19, no. 38, pp. 13-20, 2012, https://doi.org/10.3916/c38-2012$\underline{02-01}$

[3] M. Castells, La era de la información: Economía, sociedad y cultura, 3rd ed. Siglo 21 Editores, 2001.

[4] J. M. Cuenca, J. Estepa, and M. J. Martín, "El patrimonio cultural en la educación reglada," Patrim. Cult. España. Patrim. y Educ., no. 5, pp. 45-57, 2011, Accessed: May 19, 2020. [Online]. Available: https://bit.ly/3ueTIi0

[5] O. Fontal-Merillas, "Educación patrimonial: retrospectiva y prospectivas para la próxima década," Estud. Pedagógicos, vol. 52, no. 2, pp. 415-436, 2016, Accessed: May 14, 2020. [Online]. Available: https://doi.org/10.4067/s0718-07052016000200024

[6] O. Fontal, La educación patrimonial. Teoría y práctica en el aula, el museo e internet. España: Ediciones Trea, 2003.

[7] C. Gómez-Redondo, O. Fontal-Merillas, and A. Ibáñez-Etxeberria, "The use of ICT for heritage recognition and identization processes in contemporary art," Artnodes, no. 17, Sep. 2016, https://doi.org/10.7238/a.v0i17.2827

[8] V. Tserklevych, O. Prokopenko, O. Goncharova, I. Horbenko, O. Fedorenko, and Y. Romanyuk, "Virtual Museum Space as the Innovative Tool for the Student Research Practice," Int. J. Emerg. Technol. Learn. (iJET); Vol 16, No 14, Jul. 2021, https://doi.org/10. 3991/ijet.v16i14.22975

[9] E. J. Baker, J. A. Abu Bakar, and A. N. Zulkifli, "A Conceptual Model of Mobile Augmented Reality for Hearing Impaired Museum Visitors' Engagement," Int. J. Interact. Mob. Technol. (iJIM); Vol 14, No 17, Oct. 2020, https://doi.org/10.3991/ijim.v14i17.16649

[10] O. Fontal-Merillas and M. Martínez, "Evaluation of educational programmes on Intangible Cultural Heritage," Estud. Pedagog., vol. 43, no. 4, pp. 69-89, 2017, https://dx.doi.org/10 $.4067 / \mathrm{S} 0718-07052017000400004$

[11] O. Fontal-Merillas and C. Gómez-Redondo, "Evaluación de programas educativos que abordan los procesos de patrimonialización," Didáctica las Ciencias Experiementales y Soc., no. 29, pp. 89-118, 2015, https://doi.org/10.7203/dces.29.3960

[12] R. Calaf, S. Gutiérrez, and M. Suárez, "Evaluation in the Heritage Education. 20 years of research and congresses of ICOM," Aula Abierta, vol. 49, no. 1, pp. 55-64, 2020, https://doi.org/10.17811/rifie.49.1.2020.55-64 
[13] O. Fontal-Merillas and A. Ibáñez-Etxeberria, "La investigación en Educación Patrimonial. Evolución y estado actual a través del análisis de indicadores de alto impacto," Rev. Educ., 2017, https://dx.doi.org/10.4438/1988-592X-RE-2016-375-340

[14] A. Ibáñez-Etxeberria, O. Fontal-Merillas, and P. Rivero-Gracia, "Heritage education and ict in Spain: Regulatory framework, structuring variables and main points of reference," Arbor, vol. 194, no. 788, 2018, https://doi.org/10.3989/arbor.2018.788n2008

[15] D. Álvarez-Rodríguez, R. Marfil-Carmona, and C. Báez-García, "Impact research on training in mediation and education in museums: Analysis of the web of science," Rev. Electron. Interuniv. Form. del Profr., vol. 22, no. 1, pp. 121-144, 2019, https://doi.org/10.6018/ reifop.22.1.357731

[16] L. Echeverri, J. Valencia, A. Valencia, and M. Benjumea, "Evolución y tendencias investigativas de la interactividad de los museos a través de las TIC," Kepes, vol. 15, no. 18, pp. 45-80, 2018.

[17] S. Marín-Cepeda, "Cultural and artistic heritage, links and online communities. High impact indicators through ICT," Artnodes, vol. 2020, no. 26, pp. 1-9, 2020, http://dx.doi.org/10. 7238/a.v0i26.3329

[18] D. Moher, A. Liberati, J. Tetzlaff, and D. G. Altman, "Preferred Reporting Items for Systematic Reviews and Meta-Analyses: The PRISMA Statement," J. Clin. Epidemiol., vol. 62, no. 10, pp. 1006-1012, 2009, https://doi.org/10.1016/j.jclinepi.2009.06.005

[19] A.-W. Harzing and S. Alakangas, "Google Scholar, Scopus and the Web of Science: a longitudinal and cross-disciplinary comparison," Scientometrics, vol. 106, no. 2, pp. 787-804, 2016, https://doi.org/10.1007/s11192-015-1798-9

[20] D. Camps, "Limitaciones de los indicadores bibliométricos en la evaluación de la actividad científica biomédica," Colombia Médica, vol. 39. scieloco, pp. 74-79, 2008, [Online]. Available: https://bit.ly/3vkG4LW

[21] A. M. Martínez-Graña, J. A. González-Delgado, S. Pallarés, J. L. Goy, and J. C. Llovera, "3D virtual itinerary for education using Google Earth as a tool for the recovery of the geological heritage of natural areas: Application in the 'las Batuecas valley' Nature Park (Salamanca, Spain)," Sustain., vol. 6, no. 12, pp. 8567-8591, 2014, https://doi.org/10.3390/ $\underline{\mathrm{su} 6128567}$

[22] A. Dollani, A. Lerario, and N. Maiellaro, "Sustaining cultural and natural heritage in Albania," Sustain., vol. 8, no. 8, 2016, https://doi.org/10.3390/su8080792

[23] A. Gomez-Oliva, J. Alvarado-Uribe, M. C. Parra-Meroño, and A. J. Jara, "Transforming communication channels to the co-creation and diffusion of intangible heritage in smart tourism destination: Creation and testing in Ceutí (Spain)," Sustain., vol. 11, no. 14, 2019, https://doi.org/10.3390/su11143848

[24] C. Galvez, "Análisis de co-palabras aplicado a los artículos muy citados en Biblioteconomía y Ciencias de la Información (2007-2017)," Transinformação, vol. 30, no. 3, pp. 277-286, 2018, https://doi.org/10.1590/2318-08892018000300001

[25] N. J. van Eck and L. Waltman, "Software survey: VOSviewer, a computer program for bibliometric mapping," Scientometrics, vol. 84, no. 2, pp. 523-538, 2010, https://doi.org/ 10.1007/s11192-009-0146-3

[26] J. M. Correa, D. Losada, and E. Jimenez De Aberasturi, "Ideas and opinions of museums educator about the information and communication technology," Rev. Complut. Educ., vol. 23, no. 1, pp. 61-74, 2012, https://dx.doi.org/10.5209/rev_RCED.2012.v23.n1.39102

[27] M. Kampouropoulou, P. Fokiali, I. Efstathiou, T. Koutris, and E. Stefos, "Students' views on the use of a virtual educational museum," Rev. Eur. Stud., vol. 7, no. 11, pp. 1-6, 2015, https://doi.org/10.5539/res.v7n11p1 
[28] D. A. Ismaeel and A. M. Al-Abdullatif, "The impact of an interactive virtual museum on students' attitudes toward cultural heritage education in the region of Al Hassa, Saudi Arabia," Int. J. Emerg. Technol. Learn., vol. 11, no. 4, pp. 32-39, 2016, https://doi.org/ 10.3991/ijet.v11i04.5300

[29] C. A. Cassidy et al., "Digital Pathways in Community Museums," Museum Int., vol. 70, no. 1-2, pp. 126-139, 2018, https://dx.doi.org/10.1111/muse.12198

[30] L. Lucas, M. Trabajo, and B. Borghi, "The museum as a school laboratory. Good practice analysis," Arte, Individuo y Soc., vol. 32, no. 2, pp. 299-317, 2020, https://dx.doi. org/10.5209/aris.63288

[31] R. Brumana, D. Oreni, S. Caspani, and M. Previtali, "Virtual museums and built environment: Narratives and immersive experience via multi-temporal geodata hub," Virtual Archaeol. Rev., vol. 9, no. 19, pp. 34-49, 2018, https://doi.org/10.4995/var.2018.9918

[32] O. Soto-Martín, "Heritage Conservation in Secondary Education Curriculum A Didactic Proposal Based on the Application of ICT," Procedia - Soc. Behav. Sci., vol. 51, pp. 782786, 2012, https://doi.org/10.1016/j.sbspro.2012.08.240

[33] M. Kampouropoulou, "Artistic and experiential approaches - Students' attitudes on a course inspired by the new Historical center of the City of Rhodes," Rev. Eur. Stud., vol. 7, no. 11, pp. 34-44, 2015, https://doi.org/10.5539/res.v7n11p34

[34] M. Samaroudi, K. R. Echavarria, and L. Perry, "Heritage in lockdown: digital provision of memory institutions in the UK and US of America during the COVID-19 pandemic," $M u$ seum Manag. Curatorsh., vol. 35, no. 4, pp. 337-361, 2020, https://doi.org/10.1080/ 09647775.2020 .1810483

[35] P. Rivero, I. Navarro-Neri, S. García-Ceballos, and B. Aso, "Spanish archaeological museums during COVID-19 (2020): An edu-communicative analysis of their activity on twitter through the sustainable development goals," Sustain., vol. 12, no. 19, 2020, https://doi.org/10.3390/su12198224

[36] F. Dal Falco and S. Vassos, "Museum Experience Design: A Modern Storytelling Methodology," Des. J., vol. 20, no. sup1, pp. S3975-S3983, 2017, https://doi.org/10.1080/ $\underline{14606925.2017 .1352900}$

[37] A. Tzouganatou, "Can Heritage Bots Thrive? Toward Future Engagement in Cultural Heritage," Adv. Archaeol. Pract., vol. 6, no. 4, pp. 377-383, 2018, https://doi.org/10.1017/ aap. 2018.32

[38] P. G. Di Franco, M. Winterbottom, F. Galeazzi, and M. Gogan, "Ksar said: Building Tunisian young people's critical engagement with their heritage," Sustain., vol. 11, no. 5, 2019, https://doi.org/10.3390/su11051373

[39] S. Kim, D.-U. Im, J. Lee, and H. Choi, "Utility of digital technologies for the sustainability of Intangible Cultural Heritage (ICH) in Korea," Sustain., vol. 11, no. 21, 2019, https://doi.org/10.3390/su11216117

[40] M. Previtali, "A virtual logbook for the documentation of a continuously changing archaeological site: The san clemente site in Albenga (Italy)," Virtual Archaeol. Rev., vol. 10, no. 21, pp. 56-66, 2019, https://doi.org/10.4995/var.2019.11916

[41] E. Watrall, "Building Scholars and Communities of Practice in Digital Heritage and Archaeology," Adv. Archaeol. Pract., vol. 7, no. 2, pp. 140-151, 2019, https://doi.org/10. 1017/aap.2019.1

[42] I. E. Quijano-Araníbar, "The use of experimental archaeology as a didactic resource in the learning process: An educational experience with students of tourist administration in Lima, Perú," Rev. Electron. Educ., vol. 22, no. 3, 2018, https://doi.org/10.15359/ree.22-3.14

[43] X. Zabulis et al., "Representation and preservation of heritage crafts," Sustain., vol. 12, no. 4, pp. 1-26, 2020, https://dx.doi.org/10.3390/su12041461 
[44] P. Redweik, A. P. Cláudio, M. B. Carmo, J. M. Naranjo, and J. J. Sanjosé, "Digital preservation of cultural and scientific heritage: Involving university students to raise awareness of its importance," Virtual Archaeol. Rev., vol. 8, no. 16, pp. 22-34, 2017, https://doi.org/ $10.4995 / v a r .2017 .4629$

[45] P. Gutiérrez, "Strategies for Teaching and Dissemination of Artistic Heritage by Promoting Critical and Creative Thinking Among Future Primary Education Teachers," Procedia - Soc. Behav. Sci., vol. 237, pp. 717-722, 2017, https://doi.org/10.1016/j.sbspro.2017.02.112

[46] S. Jeffrey, S. Jones, M. Maxwell, A. Hale, and C. Jones, "3D visualisation, communities and the production of significance," Int. J. Herit. Stud., vol. 26, no. 9, pp. 885-900, 2020, https://doi.org/10.1080/13527258.2020.1731703

[47] A. Ibáñez-Etxeberria, N. Vicent, M. Asensio, J. M. Cuenca, and O. Fontal-Merillas, "Learning in archaeological sites with mobile devices," Munibe Antropol., vol. 65, pp. 313-321, 2014, https://doi.org/10.21630/maa.2014.65.18

[48] L. Castro, J. Rodríguez, and R. López, "Heritage education under evaluation: the usefulness, efficiency and effectiveness of heritage education programmes," Humanit. Soc. Sci. Commun., vol. 7, no. 1, 2020, https://doi.org/10.1057/s41599-020-00639-Z

[49] L. Senatore, A. Gallozzi, M. Cigola, and R. M. Strollo, "Citizen science and gamification for cultural heritage," EGA Rev. Expr. Graf. Arquit., vol. 25, no. 39, pp. 232-239, 2020, https://doi.org/10.4995/ega.2020.11586

[50] D. Ortega-Sánchez and I. M. Gómez-Trigueros, "Didactics of historical-cultural heritage QR codes and the TPACK model: An analytic revision of three classroom experiences in Spanish higher education contexts," Educ. Sci., vol. 9, no. 2, 2019, https://doi.org/10.3390 leducsci9020117

[51] L. Castro-Calviño, J. Rodríguez-Medina, C. J. Gómez-Carrasco, and R. López-Facal, "Patrimonializarte: A heritage education program based on new technologies and local heritage," Educ. Sci., vol. 10, no. 7, pp. 1-19, 2020, https://doi.org/10.3390/educsci10070176

[52] P. A. Permatasari, A. A. Qohar, and A. F. Rachman, "From web 1.0 to web 4.0: The digital heritage platforms for unesco's heritage properties in Indonesia," Virtual Archaeol. Rev., vol. 11, no. 23, pp. 75-93, 2020, https://doi.org/10.4995/var.2020.13121

[53] N. Vicent, I. Gillate, T. Campos-Lopez, and J. Castrillo, "Educational potential of Historical Memory apps. A case study,” Aula Abierta, vol. 49, no. 1, pp. 35-44, 2020, https://doi.org /10.17811/rifie.49.1.2020.35-43

[54] A. Ibáñez-Etxeberria, A. Kortabitarte, P. De Castro, and I. Gillate, "Digital competence using heritage theme apps in the DigComp framework," Rev. Electron. Interuniv. Form. del Profr., vol. 22, no. 1, pp. 13-27, 2019, https://doi.org/10.6018/reifop.22.1.356231

[55] Ú. Luna, P. J. C. Herrera, A. Z. González, and A. Ibáñez-Etxeberria, “Apps, education and heritage in Mexico. Situation analysis and comparative study with the Spanish case," Aula Abierta, vol. 49, no. 1, pp. 9-16, 2020, https://doi.org/10.17811/rifie.49.1.2020.9-16

[56] A. Martínez, J. Á. González-Delgado, C. Ramos, and J. C. Gonzalo, “Augmented reality and valorizing the Mesozoic Geological Heritage (Burgos, Spain)," Sustain., vol. 10, no. 12, 2018, https://doi.org/10.3390/su10124616

[57] C. R. Cunha et al., "Boosting cultural heritage in rural communities through an ICT platform: The Viv@vó Project,” IBIMA Bus. Rev., vol. 2019, 2019, https://doi.org/10.5171/ $\underline{2019.608133}$

[58] L. Hanes and R. Stone, "A model of heritage content to support the design and analysis of video games for history education," J. Comput. Educ., vol. 6, no. 4, pp. 587-612, 2019, https://doi.org/10.1007/s40692-018-0120-2

[59] C. E. Jones, S. Theodosis, and I. Lykourentzou, "The enthusiast, the interested, the sceptic, and the cynic: Understanding user experience and perceived value in location-based cultural 
heritage games through qualitative and sentiment analysis," J. Comput. Cult. Herit., vol. 12, no. 1,2019 , https://doi.org/10.1145/3297716

[60] J. Cepeda and O. Fontal-Merillas, "Survey design to identify the forms of identity relationship in Castile and Leon," Rev. Electron. Interuniv. Form. del Profr., vol. 22, no. 1, pp. 2940, 2019, https://dx.doi.org/10.6018/reifop.22.1.356031

[61] J. Delgado Rubio, "Mutual education. Towards a model of educational co-creation around the archaeological heritage of Mexico," AP Online J. Public Archaeol., vol. 8, no. 1, pp. 733, 2019, https://doi.org/10.23914/ap.v8i1.177

[62] A. Briciu, V.-A. Briciu, and A. Kavoura, "Evaluating how 'smart' Brasov, Romania can be virtually via a mobile application for cultural tourism," Sustain., vol. 12, no. 13, 2020, https://doi.org/10.3390/su12135324

[63] S. Tzima, G. Styliaras, A. Bassounas, and M. Tzima, "Harnessing the potential of storytelling and mobile technology in intangible cultural heritage: A case study in early childhood education in sustainability," Sustain., vol. 12, no. 22, pp. 1-22, 2020, https://doi.org/10. $\underline{3390 / \mathrm{su} 12229416}$

[64] T. D. Tvedebrink and N. C. Bagger, "The chairs of venice applying storytelling as teaching method to understand material cultural heritage," Res Mobilis, vol. 9, no. 11, pp. 124-147, 2020, https://doi.org/10.17811/rm.9.11.2020.124-147

[65] J. G. Andrade and P. Dias, "A phygital approach to cultural heritage: Augmented reality at regaleira," Virtual Archaeol. Rev., vol. 11, no. 22, pp. 15-25, 2020, https://doi.org/10.4995/ var.2020.11663

[66] R. Mendoza, S. Baldiris, and R. Fabregat, "Framework to Heritage Education Using Emerging Technologies," Procedia Comput. Sci., vol. 75, pp. 239-249, 2015, https://doi.org/10. 1016/i.procs.2015.12.244

[67] C. Ciurea and F. G. Filip, "The globalization impact on creative industries and cultural heritage: A case study," Creat. Stud., vol. 12, no. 2, pp. 211-223, 2019, https://doi.org/ $\underline{10.3846 / \text { cs.2019.7753 }}$

[68] L. Martínez-Solís and C. Chaín-Navarro, "Digital Humanities for learning and dissemination of the Naval Heritage," Rev. Educ. a Distancia, no. 57, 2018, https://dx.doi.org/ $10.6018 / \mathrm{red} / 57 / 9$

[69] P. Tanta-O-Pas, S. Chantachon, and M. Koseyayothin, “Thai musical instruments: Development of innovative multimedia to enhance learning among secondary level education students (M.1 to M.3) in Bangkok," Asian Soc. Sci., vol. 9, no. 13, pp. 163-168, 2013, https://doi.org/10.5539/ass.v9n13p163

[70] M. D. Teruel and M. J. Viñals, "Evaluating the communication efficiency of the websites at the archaeological and heritage destination of Cartagena (Spain)," Virtual Archaeol. Rev., vol. 9, no. 18, pp. 87-94, 2018, https://dx.doi.org/10.4995/var.2018.6831

[71] A. van der Hoeven, "Valuing Urban Heritage Through Participatory Heritage Websites: Citizen Perceptions of Historic Urban Landscapes," Sp. Cult., vol. 23, no. 2, pp. 129-148, 2020, https://doi.org/10.1177/1206331218797038

[72] D. de S. Price, Little Science, Big Science... and beyond. Nueva York: Columbia University Press, 1986.

\section{Authors}

Jacob Vargas Arteaga, Degree in Educational Informatics and Audiovisual Media and a Master degree on Education at the University of Córdoba, Colombia. Doctorate Candidate in Educational Sciences at Universidad Simón Bolívar, Colombia. 
Marbel Lucía Gravini-Donado, Degree in Psychology and a Master's degree in Education from the Fundación Universidad del Norte, Colombia. Doctor in Education from Universidad Autónoma de Madrid, Spain. Teacher and leader researcher of the Educational and Social Synapse Group of the Universidad Simón Bolívar, Colombia. Senior Researcher of the Ministry of Science and Technology of Colombia (Email: mgravini1@unisimonbolivar.edu.co).

Lorenzo Domenico Zanello Riva, Degree in Economics from Universidad del Norte, Colombia. Doctor in Social Sciences from Universidad del Norte, Colombia. Research and Development Director at Altamira International School, Colombia (Email: lorenzo.zanello@unisimon.edu.co).

Article submitted 2021-06-29. Resubmitted 2021-08-01. Final acceptance 2021-08-01. Final version published as submitted by the authors. 